\title{
Editorial
}

\section{Dietary Antioxidants and Metabolic Diseases}

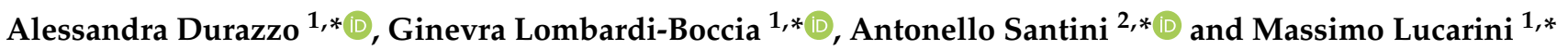 \\ 1 CREA-Research Centre for Food and Nutrition, Via Ardeatina 546, 00178 Rome, Italy \\ 2 Department of Pharmacy, University of Napoli Federico II, Via D. Montesano 49, 80131 Napoli, Italy \\ * Correspondence: alessandra.durazzo@crea.gov.it (A.D.); g.lombardiboccia@crea.gov.it (G.L.-B.); \\ asantini@unina.it (A.S.); massimo.lucarini@crea.gov.it (M.L.)
}

check for updates

Citation: Durazzo, A.; Lombardi-Boccia, G.; Santini, A.; Lucarini, M. Dietary Antioxidants and Metabolic Diseases. Int. J. Mol. Sci. 2021, 22, 12558. https://doi.org/ $10.3390 /$ ijms222212558

Received: 10 November 2021 Accepted: 15 November 2021 Published: 22 November 2021

Publisher's Note: MDPI stays neutral with regard to jurisdictional claims in published maps and institutional affiliations.

Copyright: (C) 2021 by the authors. Licensee MDPI, Basel, Switzerland. This article is an open access article distributed under the terms and conditions of the Creative Commons Attribution (CC BY) license (https:// creativecommons.org/licenses/by/ $4.0 /)$.

\section{Introduction}

Considering the change in people's diets and lifestyle, the number of people with metabolic diseases such as diabetes, obesity and gout is on the rise. Some studies have shown that dietary antioxidant nutrients (e.g., ascorbic acid, $\beta$-carotene, vitamin $\mathrm{E}$ and selenium) can have preventive and therapeutic effects on some metabolic diseases. Moreover, antioxidants are substances that may protect cells against free radicals, which may play a role in health conditions [1-3].

Nonetheless, the real impact of these dietary antioxidants and their mechanisms of action is far yet to be completely elucidated. Preclinical and/or human evidence are essential elements. Many foods in the human diet, such as vegetables and fruits, contain antioxidants that may act interactively, even synergistically, with the endogenous antioxidant defense system to restore or maintain redox homeostasis. Some phytochemicals can influence the pathways of molecular signal transduction such as inflammation cascades, metabolic disorders and oxidative stress.

The treatment of metabolic diseases includes a healthy and balanced diet, and supplementation with nutraceuticals [4-12].

To give a current snapshot of the interest raised in the international research context within this topic, a search throughout the Scopus online database was carried out by means of a string TITLE-ABS-KEY ("dietary antioxidant" AND "health*"). The "full records and cited references" were exported and processed using the VOSviewer software (version 1.6.16, 2020; www.vosviewer.com, accessed on 6 November 2021) [13-15]. The search returned 822 publications covering the time range from 1973 to 2022, and a total of 830 terms were identified and visualized as a term map in Figure 1.

Figure 1 allows us to identify the main terms correlated with research on the relationship between dietary antioxidants and health and identifies the main existing research lines focused on this topic. It is interesting to observe that, among the top-recurring keywords, antioxidants, humans, male, female, adult, ascorbic acid, alpha tocopherol, oxidative stress, diet, dietary intake and antioxidant activity appear. The most cited paper (2271 times) is the review by Pandey and Rizvi [16] on plant polyphenols as dietary antioxidants in human health and disease.

This Special Issue is focused on recent advances in the study of the health benefits of dietary antioxidants in metabolic diseases as well as on the discovery of novel molecular therapeutic mechanisms and the testing of novel targeted therapies.

A current challenge is given by combing through databases, repositories, and infrastructures to link information and compositive data on antioxidant to metabolomic pathways and biomarkers from the perspective of interoperability [17-19]. 


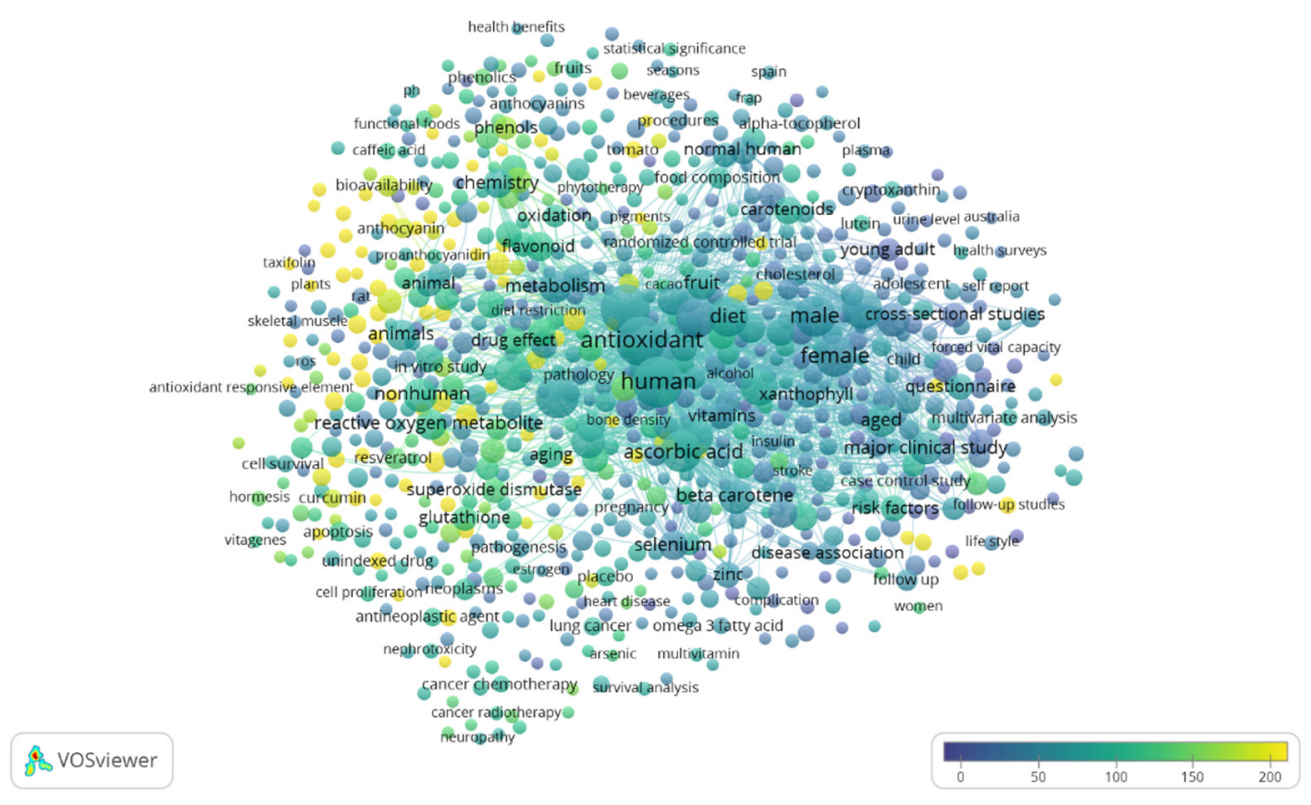

Figure 1. Term map for the relationship between dietary antioxidant and health research. Bubble size represents the number of publications. Bubble color represents the citations per publication (CPP). Two bubbles are closer to each other if the terms co-appeared more frequently (bibliometric data were extracted from the Scopus online database and elaborated by the VOSviewer software).

Author Contributions: A.D., G.L.-B., A.S. and M.L. made substantial, direct and intellectual contributions to this work and approved it for publication. All authors have read and agreed to the published version of the manuscript.

Funding: This research received no external funding.

Conflicts of Interest: The authors declare no conflict of interest.

\section{References}

1. Halliwell, B.; Gutteridge, J.M.C. Free Radicals in Biology and Medicine, 3rd ed.; Oxford University Press: New York, NY, USA, 1999.

2. Lobo, V.; Patil, A.; Phatak, A.; Chandra, N. Free radicals, antioxidants and functional foods: Impact on human health. Pharmacogn. Rev. 2010, 4, 118-126. [CrossRef] [PubMed]

3. Kurutas, E.B. The importance of antioxidants which play the role in cellular response against oxidative/nitrosative stress: Current state. Nutr. J. 2016, 15, 71. [CrossRef] [PubMed]

4. Derosa, G.; Maffioli, P. Nutraceuticals for the treatment of metabolic diseases: Evidence from clinical practice. Expert Rev. Endocrinol. Metab. 2015, 10, 297-304. [CrossRef] [PubMed]

5. Santini, A.; Novellino, E. Nutraceuticals in hypercholesterolaemia: An overview. Br. J. Pharmacol. 2017, 174, 1450-1463. [CrossRef] [PubMed]

6. Durazzo, A. Extractable and non-extractable polyphenols: An overview. In Non-Extractable Polyphenols and Carotenoids: Importance in Human Nutrition and Health; Saura-Calixto, F., Pérez-Jiménez, J., Eds.; RSC Publishing: Cambridge, UK, 2018; pp. 37-45. ISBN 978-1-78801-447-2. [CrossRef]

7. Durazzo, A.; Lucarini, M.; Souto, E.B.; Cicala, C.; Caiazzo, E.; Izzo, A.A.; Novellino, E.; Santini, A. Polyphenols: A concise overview on the chemistry, occurrence, and human health. Phytother. Res. 2019, 33, 2221-2243. [CrossRef] [PubMed]

8. Durazzo, A.; Lucarini, M. The State of science and innovation of bioactive research and applications, health, and diseases. Front. Nutr. 2019, 6, 178. [CrossRef] [PubMed]

9. Durazzo, A.; Lucarini, M.; Novellino, E.; Souto, E.B.; Daliu, P.; Santini, A. Abelmoschus esculentus (L.): Bioactive Components' Beneficial Properties-Focused on Antidiabetic Role-For Sustainable Health Applications. Molecules 2019, 24, 38. [CrossRef] [PubMed]

10. Vieira, R.; Souto, S.B.; Sánchez-López, E.; López Machado, A.; Severino, P.; Jose, S.; Santini, A.; Fortuna, A.; García, M.L.; Silva, A.M.; et al. Sugar-Lowering Drugs for Type 2 Diabetes Mellitus and Metabolic Syndrome-Review of Classical and New Compounds: Part-I. Pharmaceuticals 2019, 12, 152. [CrossRef] [PubMed]

11. Durazzo, A.; Camilli, E.; D'Addezio, L.; Piccinelli, R.; Mantur-Vierendeel, A.; Marletta, L.; Finglas, P.; Turrini, A.; Sette, S. Development of Dietary Supplement Label Database in Italy: Focus of FoodEx2 Coding. Nutrients 2020, 12, 89. [CrossRef] [PubMed] 
12. Cena, H.; Calder, P.C. Defining a Healthy Diet: Evidence for The Role of Contemporary Dietary Patterns in Health and Disease. Nutrients 2020, 12, 334. [CrossRef] [PubMed]

13. Waltman, L.; van Eck, N.J.; Noyons, E.C. A unified approach to mapping and clustering of bibliometric networks. J. Inf. 2010, 4, 629-635. [CrossRef]

14. Van Eck, N.J.; Waltman, L. Software survey: VOSviewer, a computer program for bibliometric mapping. Scientometrics 2010, 84, 523-538. [CrossRef] [PubMed]

15. Van Eck, N.J.; Waltman, L. Text mining and visualization using VOSviewer. ISSI Newslett. 2011, 7, 50-54.

16. Pandey, K.B.; Rizvi, S.I. Plant polyphenols as dietary antioxidants in human health and disease. Oxidative Med. Cell. Longev. 2009, 2, 270-278. [CrossRef] [PubMed]

17. Plumb, J.; Durazzo, A.; Lucarini, M.; Camilli, E.; Turrini, A.; Marletta, L.; Finglas, P. Extractable and non-extractable antioxidants composition in the eBASIS database: A key tool for dietary assessment in human health and disease research. Nutrients 2020, 12, 3405. [CrossRef] [PubMed]

18. Dwyer, J.T.; Saldanha, L.; Bailen, R.; Durazzo, A.; Le Donne, C.; Piccinelli, R.; Andrews, K.; Pehrsson, P.; Gusev, P.; Calvillo, A.; et al. Commentary: An impossible dream? Integrating Dietary Supplement Label Databases needs, challenges, next Steps. J. Food Compos. Anal. 2021, 102, 103882. [CrossRef]

19. Misra, B.B. New software tools, databases, and resources in metabolomics: Updates from 2020. Metab. Off. J. Metab. Soc. 2021, 17, 49. [CrossRef] [PubMed] 